\title{
Effects of Occupational Environment on Employee Performance in Sugar Industries in Western Kenya
}

\author{
Sylvia Bisela Simiyu, (BSc) -Graduate Student - Kibabii University - Kenya \\ E-mail: sylviasimiyu79@gmail.com
}
Muganda Munir Manini, (PhD),-Senior Lecturer, Kibabii University - Kenya
E-mail: mmanini@kibu.ac.ke

\begin{abstract}
Victor Lusala Aliata, (PhD),-Lecturer, Tom Mboya University College- Kenya
E-mail:vlusala@tmuc.ac.ke
\end{abstract}

Received: Oct. 5, 2019 Accepted: Jul. 20, 2020 Online published: Aug. 31, 2020

doi:10.5296/ijhrs.v10i3.17607ＵRL: https://doi.org/10.5296/ijhrs.v10i3.17607

\begin{abstract}
The Occupational Safety and Health Act No. 15 of 2007 and reread in 2010, offers for the safety health and benefit of personnel and all individuals lawfully current at places of employment in Kenya. Despite this workers have continued to face occupational health and safety challenges which expose them to a wide range of accidents which eventually pull down their performance. According to ILO statistics on safety and health at work of 28th April 2016, 6300 individuals succumb daily due to occupational accidents or employment associated ailments and deaths exceeding 2.3 million yearly. The study was purposed to investigate the effect of occupational health and safety (OHS) on employee performance in Sugar Industries in Western Kenya. The explicit objective was to determine the effects of occupational environment on employee performance in sugar industries in Western Kenya. The target population comprised 8801 staff in all the sugar firms in Western Kenya. Stratified random sampling technique was used to select a sample of 383. Primary data was gathered by use of questions which were validated through a pilot study of 10 staff prior to the main research. Cronbach alpha coefficient with a threshold of 0.70 was used to test the reliability of the research instrument. The study findings revealed that: occupational environment contributed to employee performance $\beta=0.585$. The $\mathrm{R}^{2}$ change after incorporating Top Management Support was $0.290, \mathrm{P}=0.000$ implying that TMS statistically moderates the relationship between occupational health and safety and employee performance. Study concluded that:
\end{abstract}


Occupational environment has a significant effect on employee performance while TMS has a significant moderator and influences the relationship between OHS and employee performance.

Keywords: occupational health, employee performance, occupational environment, sugar manufacturing industries in Kenya

\section{Introduction}

Human Resources is the most important component in the organization and in the implementation of the production process hence employees of an organization just like other resources need care and maintenance so as to maximize their productivity and improve performance (Makori Ezekiel, Elisha, Norah Otabo, 2012). Therefore organizations should pay attention to maintaining Occupational Safety and Health (OSH) of their employees. This is done to provide comfort while working and the resulting sense of security for the workers at the time of the production process and when dealing directly with their work environment (Rachmawati, 2013).

It is the obligation of organizations to pay attention to sustaining Occupational Safety and Health (OSH) of their staffs. The motive for this is to give comfort while occupied and the ensuing sense of security for the workers at the time of the production process and when dealing directly with their work environment (Abuga, 2012). Human resource managers therefore, currently are facing challenges as appertains to issues in regard to occupational health and safety (Makori et al., 2012).

Good health at work and conducive working environments are valued factors by employees, communities and countries. Creating a work place that attracts, maintains and motivates the workforce is one of the biggest and modern challenges that organizations are facing today (Simiyu, 2013). This calls for the management team to explore new ways of countering this challenge by instituting drastic, accurate and up-to-date mechanisms that will make the workplace environment exciting; a work place environment in which workers enjoy their job reveal a purpose for work and give them a reason to be proud of working and enabling them to reach their potential (Hirba and Nzulwa, 2017).

Currently in Kenya, the position of OSH guidelines has been an issue of increasing significance. At present, the directorate of Occupational Safety and Health Services (DOSHS) is domiciled in the Government of Kenya, Ministry of Labour, Social Security and Services.

However, reports show that cases exceeding a half of all injuries and accidents at work place were not reported. This led to the enactment of Occupational Safety and Health Act (OSHA) 2007 with an aim of solving OSH cases amicably (Nyakang'o 2005). Occupational safety and health issues majorly arise when matters of safety are taken nonchalantly by both the employer and employees. The total number of victims involved in accidents is surging, showing an indicator that working environment is very hazardous (Mberia, 2001).

Workers at Sugar cane industries are exposed to different working hazards depending on the working activity. Working conditions which are not conducive result to ergonomic problems 
viz musculoskeletal disorder, repetitive work strain, and accidents. Workers faced accidents or injuries frequently due to hand tools (Melville, 1999). With the use of manual sugar cane stripper, physiological cost of sugar is reduced from 43 beats to 33 beats (Mohanta \& Patra, 2015).

According to International Finance Corporation of World Bank Group, to minimize work threat factors, the Environment, Health and Safety (EHS) guidelines should be adhered to by sugar industries (International Finance Corporation, 2007). In order to determine occupational health and safety practices, this study is an attempt to investigate the effect if occupational and safety on employee performance in Sugar Industries in Western Kenya. Workers at sugar industries are at a higher risk of getting work related ailments, injuries, accidents and health threatening risks. Workers are likely to encounter various occupational risks ranging from physical to biological and chemical hazards at the plant. The exhaust steam from evaporators and the vacuum pans are a major cause of the hot working environment.

This has resulted to reduced working time hence reduced productivity of a worker. Further, workers in thermal load sections are operating in stressful thermal conditions due to their proximity to the heat source combined with the lack of proper safety thermal protective wear and they are most prone to physical fatigue, weak limbs and dehydration It was also reported by the relationship between the working posture and the machinery affected the workers muscles and joints. The machinery is not designed to minimize adverse effects of poor working posture among the workers in the plant.

\subsection{Statement of the Problem}

According to ILO statistics on health and safety at workplace, the study results released on $28^{\text {th }}$ April 2016, 6300 people depart each day so the end result concerning occupational misfortunes hitherto work connected diseases is greater than 2.3 lot deaths throughout the year. Studies performed on occupational health and safety of employees and performance band by Ayub (2010) performed a study over the sum concerning assent along Occupational Safety and Health law at registered places of work within Nairobi, Muchangi (2009) did on evaluation of Occupational Health Hazards Management of Construction Industry at Moi University, Kenya, Ndirangu or Namusonge (2014) conveyed out a lookup regarding factors influencing implementation concerning occupational health then security a suit discipline about Kenya vehicle manufacturers into Thika and Mutuli and Lubwama (2016) did a research on warm pursuit environments: a critical look at a ordinary gravel manufactured difficulty of Kenya. From the overall studies none has been conducted in the larger Western Kenya involving sugar industries, consequently the existing gap. It is along this line up to expectation. that the researcher went ahead and conducted a research on the impact of occupational health and safety on employee performance in Western Kenya sugar industries.

\subsection{Specific Objective of the Study}

This research was to fulfill the following specific objective:

To determine the outcomes on occupational environment on employee overall performance in sugar manufacturing industries in Western Kenya 


\subsection{Research Hypotheses}

From the above objective the study formulates the following hypothesis:

$\mathbf{H}_{\mathbf{0}}$ : Occupational environment has no significant effect on employee performance in sugar industries in Western Kenya

\section{Literature Review}

\subsection{Distractions Theory}

The proponent of the theory is Hinze (1997) and states that safety is situational. Because mental distractions vary, the responses to them may have to differ to maintain safe performance. Additionally, hazards or physical conditions with inherent qualities that can cause harm to a person, may or may not be recognized by the worker and influence safety of the task. The theory applies to a situation in which recognized safety hazard or mental distractions exist and there is a well-defined work task to perform. In the absence of hazards there is little to prevent workers from completing their tasks. However in the presence of hazards, work is greatly complicated. The theory has two components, first dealing with hazards posed by unsafe physical conditions and the other dealing with a worker preoccupation with issues not directly related to the task being performed. The theory was vital in this study since it was used to guide occupational environment which in this study was conceptualized as physical and social environment. The main tenet of the theory is that safety is situation implying that safety relates to the location and surroundings of a place.

\subsection{Occupational Health and Safety}

Occupational security is the renovation of a labor environment that is remarkably free from authentic or practicable exposures that can scar employees (Pollitt, 2011). Also in accordance with WHO (2013) Occupational health and safety is described as the chastisement that deals with the deterrence of labor related injuries and ailments as properly as the safety and merchandising of the health of workers. It targets at the enhancement of working stipulations and environment. Members of many exceptional professions such as hygienists, engineers, psychologists, nurses and physicians make contributions to "occupational health, occupational safety, occupational hygiene, welfare at work and enhancement of the working surroundings" (Prabakar, 2013).

\subsubsection{Occupational Environment}

Occupational environment is defined as the establishment and other locations where one or a group of employees are working or are present as a condition of their employment. Amir and Shamim (2013) defined occupational gave the definition of environment as including two components; physical and behavioral. The physical environment entails components associated to office bearer's capacity to physically bond with the work environment. The second component which is behavioral environment entails factors that are linked to the ability of employees to relate well with each other. 
Occupational environment influences employee performance hugely either negatively or positively (Chandrasekar, 2011). Majorly, a higher percentage of individuals spent much time contained by indoor environments hence significantly affecting their actions, mental status performance and abilities (Noble, 2009). Enhanced performance of employees is as a result of good occupational environment. Healthier occupational environment at work place will result to superior productivity (Bushiri, 2014).

According to Strawa and Sayles (1980) they allude that it is till recently that managers put in consideration that employees Health and Safety is an issue of more concern to the organization. The dangerously installed and not so well maintained workshops in the beginning of industrial revolution have become history with this realization. There has been redesign and re engineering of office space and equipment to ensure employee health and safety. Employees have been provided with safety gear to be worn where applicable.

Employee Health and safety today is a complex, multidimensional problem which needs a holistic approach (WHO, 2012). Ismail et al. (2010) opines by stating that the physical workplace environment determines the workmanship of a worker either negatively or positively. Temperature, office layout, work setting or arrangement and comfort zone are examples of physical environment. Also it entails furniture, noise, lighting and spatial layouts in workplaces (Vischer, 2007).

According to Niemela (2002), it was found that there was decrease in productivity when temperatures were high, and low temperatures were related to higher performance of physical jobs. According to McCoy and Evans (2005) physical environment components need to be appropriate so as to induce performance of employees. Vischer (2008) insists that workplace environment should be given priority as it motivates employees to perform even better.

\subsection{Employee Performance}

Work execution can be pigeon-holed as the triumph of shown errand assessed in contrast to stated measures of cost, precision, speed and fulfillment. Work pact, execution is considered as success of an obligation in an approach that releases the entertainer from total obligations undersigned in the agreement. Worker execution is indispensable for business achievement. The writing distinguishes factors, for example, professional stability, outstanding burden, non-attendance, and maintenance and on-and off-the-work preparing as influencing worker execution (Pollitt, 2014). Worker turnover, fulfillment, responsibility, Esprit de-corps and citizenship are some different determinants of representative execution (Samuelson and Nordhaus, 2014). Duty alludes to how much representatives penance for, relate to and include themselves in accomplishing authoritative goals. Worker connection and dependability are different proportions of representative responsibility. Esprit de corps identifies with collaboration and attachment with regards to an association. It implies worker connection to accomplish normal hierarchical destinations. Compelling authoritative initiative and conduct make pride, duty and commitment in representatives, which are significant determinants of esprit de corps (Badelake, 2012).

Worker execution can be translated to mean the business income per representative. While 
various result measures have been utilized to determine then viability of HR frameworks, an essential spotlight on worker execution is justified for various reasons. In the first place, worker execution is a critical hierarchical result. At a general level, representative execution, characterized as "absolute yield isolated by work inputs" (Samuelson \&Nordhaus, 2012), demonstrates the degree to which an association's work power is effectively making yield. Second, since associations between human capital and worker execution are generally immediate, the face legitimacy for this proportion of firm achievement is additionally moderately high (Dyer and Reeves, 1995). Third, SHRM scholars have recognized representative execution as the urgent marker of work power execution (Abuga, 2012). At last, worker execution has been the most every now and again utilized result variable in an enormous group of work in the SHRM writing (Boles, Pelletier, and Lynch, 2012).

\section{Research Methodology}

\subsection{Research Design}

The research design used is exploration configuration. It embraces distinct overview of research structures. The factors were chosen to help answer research questions, to test speculations, and were picked dependent on a hypothesis or hypotheses that underlies the clarification proposed for the marvel being inspected (Denscombe, 2014).

\subsection{Target Population}

A populace is the entire gathering of people, occasions or items having basic obvious highlights.

In this investigation, the objective populace will involve 8859 representatives in all the sugar firms in Western Kenya (KSB, 2015; Firms Employee Database, 2015). The sugar firms include Nzoia sugar, Muhoroni sugar, Mumias Sugar, Chemelil Sugar, Butali Sugar and West Kenya sugar.

\subsection{Sample Size}

Yamane (1967:886) formulation was embraced to reckon a suitable sample for the study which consisted of all the staff and managers. The sample size was 383 respondents. A total of 380 questionnaires were distributed and 317 valid questionnaires were returned. This implies that the response rate was $83.7 \%$ of the sample size.

\subsection{Questionnaires, Validity and Reliability}

The questionnaires were presented to respondents in their original form. Validity of questionnaires was determined through a pilot investigation of 10 staff before of Nzoia sugar before the primary research. Cronbach alpha was calculated to determine reliability of research instruments as shown in table 1 below. 


\section{Macrothink}

International Journal of Human Resource Studies

ISSN 2162-3058 2020, Vol. 10, No. 3

Table 1. Cronbach Alpha

\begin{tabular}{lcc}
\hline Construct & Cronbach's Alpha & No. of items \\
\hline Occupational Environment & 0.704 & 6 \\
Working Culture & 0.759 & 6 \\
Working Capacity of Health workers & 0.880 & 8 \\
Occupational risk & 0.827 & 6 \\
Top Management Support & 0.729 & 6 \\
Employee Performance & 0.802 & 12 \\
All the constructs combined & 0.784 & 44 \\
\hline
\end{tabular}

Table 1 above indicates the unwavering quality coefficient for every one of the builds utilized in this investigation which was 0.784, which surpassed the 0.6 lower level of worthiness (Hair et al., 2006) and inside the 0.70 or more as recommended by Nunnally (1978) and accordingly solid and adequate for further examination. This shows that the validity and reliability of research instruments used in this study was achieved.

\section{Descriptive on Research Variable}

\subsection{Occupational Environment}

The inspected respondents were solicited to express their level from concession to six proclamations identified with work related condition. The outcomes are as appeared in Table 2 below

Table 2. Descriptive occupational environment

\begin{tabular}{|c|c|c|c|c|c|c|}
\hline $\begin{array}{l}\text { Occupational } \\
\text { Environment }\end{array}$ & $\mathrm{N}$ & Mean & SE & STDV & Skewness & Kurtosis \\
\hline $\begin{array}{l}\text { Workplace is not } \\
\text { crowded, clean, well } \\
\text { lit, well ventilated and has } \\
\text { well drained floors }\end{array}$ & 317 & 3.11 & 0.061 & 1.091 & -0.389 & -0.615 \\
\hline $\begin{array}{l}\text { Workplace is supplied } \\
\text { with drinking water, clean } \\
\text { toilets/latrines separate for } \\
\text { each gender and adequate } \\
\text { sitting facilities }\end{array}$ & 317 & 3.20 & 0.059 & 1.058 & -0.349 & -0.215 \\
\hline $\begin{array}{l}\text { Workplace has adequate } \\
\text { firefighting equipment } \\
\text { and workers trained on } \\
\text { their use }\end{array}$ & 317 & 3.36 & 0.059 & 1.042 & -0.374 & -0.391 \\
\hline $\begin{array}{l}\text { Workers are provided with } \\
\text { emergency procedures } \\
\text { which are regularly tested }\end{array}$ & 317 & 2.97 & 0.052 & 0.924 & -0.240 & -0.272 \\
\hline $\begin{array}{l}\text { Workers are provided with } \\
\text { personal protective } \\
\text { equipment if needed and } \\
\text { trained on their use }\end{array}$ & 317 & 3.37 & 0.057 & 1.006 & -0.416 & -0.522 \\
\hline $\begin{array}{l}\text { Workplace has well } \\
\text { maintained and } \\
\text { unobstructed means of } \\
\text { escape in case of a fire }\end{array}$ & 317 & 3.37 & 0.062 & 1.105 & -0.678 & -0.471 \\
\hline Overall & & 3.23 & 0.058 & 1.038 & -0.408 & -0.414 \\
\hline
\end{tabular}

Table 2 above point out how occupational environment affects employee performance. All the 
items have high mean of above 3 which designates that they affect performance positively. Therefore it can be concluded that occupational environment affects positively employee performance of sugar companies in Western Kenya.

\subsection{Employee Performance}

The tested respondents were solicited to express their level from concession to 12 proclamations identified with representative execution because of word related wellbeing and security. The outcomes are as appeared in Table 4 below

Table 4. Employee Performance

\begin{tabular}{|c|c|c|c|c|c|c|}
\hline Employee performance & $\mathrm{N}$ & Mean & $\mathrm{SE}$ & SDV & Skewness & Kurtosis \\
\hline $\begin{array}{l}\text { Due to OSH practices, I } \\
\text { am able to produce } \\
\text { accurate work as expected } \\
\text { by my organization. }\end{array}$ & 317 & 3.37 & 0.064 & 1.136 & -0.480 & -0.383 \\
\hline $\begin{array}{l}\text { OHS practices has instill } \\
\text { the right attitudes } \\
\text { necessary to produce } \\
\text { desired performance }\end{array}$ & 317 & 3.21 & 0.062 & 1.111 & -0.308 & -0.685 \\
\hline $\begin{array}{l}\text { OHS practices has } \\
\text { improves the employees } \\
\text { utilization as they develop } \\
\text { skills useful to the } \\
\text { company }\end{array}$ & 317 & 4.03 & 0.055 & 0.980 & -1.118 & 0.770 \\
\hline $\begin{array}{l}\text { I am always motivated, } \\
\text { productive and creative as } \\
\text { a result of OHS practices } \\
\text { of my organization. }\end{array}$ & 317 & 3.97 & 0.051 & 0.915 & -0.990 & 0.926 \\
\hline $\begin{array}{l}\text { OHS practices have } \\
\text { allowed me to plan and be } \\
\text { able to undertake work in } \\
\text { an organized manner }\end{array}$ & 317 & 3.44 & 0.063 & 1.119 & -0.362 & -0.967 \\
\hline $\begin{array}{l}\text { I have established good } \\
\text { working relation with the } \\
\text { coworkers due } \\
\text { practices } \\
\text { organization }\end{array}$ & 317 & 3.00 & 0.065 & 1.157 & 0.080 & -0.994 \\
\hline $\begin{array}{l}\text { I am not aggressive and } \\
\text { depressed at work and } \\
\text { therefore can perform my } \\
\text { duties effectively }\end{array}$ & 317 & 2.29 & 0.079 & 1.408 & 0.711 & -0.917 \\
\hline $\begin{array}{l}\text { OHS enhanced my } \\
\text { punctuality in meeting my } \\
\text { work deadlines }\end{array}$ & 317 & 3.77 & 0.047 & 0.843 & -0.141 & -0.511 \\
\hline $\begin{array}{l}\text { I am satisfied with my day } \\
\text { to day responsibilities and } \\
\text { activities at my work place }\end{array}$ & 317 & 2.95 & 0.061 & 1.093 & -0.031 & -0.698 \\
\hline $\begin{array}{l}\text { OHS improves the } \\
\text { employees ability to reach } \\
\text { the desired output based } \\
\text { on targets set or defined }\end{array}$ & 317 & 3.36 & 0.053 & 0.949 & -0.163 & -0.036 \\
\hline $\begin{array}{l}\text { I have become more } \\
\text { competent in my job as a }\end{array}$ & 317 & 2.83 & 0.062 & 1.107 & 0.052 & -0.879 \\
\hline
\end{tabular}


results of OHS practices The OHS practices in my organization has resulted to attracting new employees and retaining existing one Overall

Table 4 above shows that OHS practices has improves the representatives usage as they create abilities valuable to the organization and I am constantly roused, gainful and imaginative because of OHS practices of my association had positive kurtosis.

\subsection{Correlation of Occupational Environment and Employee Performance in Sugar} Industries in Western Kenya

The Pearson correlation analysis was used to check out the relationship between occupational environment and employee performance. The correlation strengths were interpreted the use of Cohen (1988) choice policies where $r$ values from 0.1 to 0.3 indicate susceptible correlation, 0.31 to 0.5 indicate reasonable correlation power and increased than 0.5 indicate a sturdy correlation between the variables.

The outcomes are as shown in Table 5

Table 5. Correlation of Occupational Environment and Employee Performance

\begin{tabular}{llll}
\hline & Correlation Coefficient & $\begin{array}{l}\text { Occupational } \\
\text { environment }\end{array}$ & Performance \\
\hline Occupational environment & Sig. (2-tailed) & 0.000 & \\
& $\mathrm{~N}$ & 317 & \\
& Correlation Coefficient & $0.529^{* *}$ & 1.000 \\
Employee Performance & Sig. (2-tailed) & 0.000 & \\
& $\mathrm{~N}$ & 317 & 317 \\
\hline
\end{tabular}

**. Correlation is significant at the 0.01 level (2-tailed).

In identifying the effect of occupational surroundings on worker performance, the study set up a coefficient of correlation ( $\mathrm{r}$ ) as $0.529 * *$. The outcomes indicated that the relationship between occupational surroundings and worker performance is advantageous and significant.

\subsection{Regression Results of Occupational environment and employee performance}

Table 6. Regression Results of Occupational Environment and Employee Performance

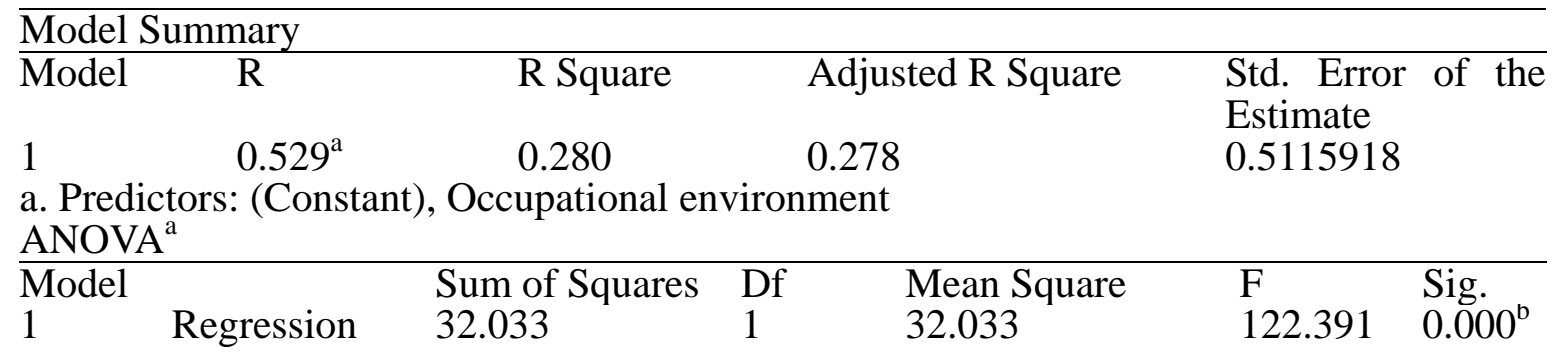




$\begin{array}{llll}\text { Residual } & 82.444 & 315 & 0.262 \\ \text { Total } & 114.477 & 316 & \end{array}$

a. Dependent Variable: Employee Performance

b. Predictors: (Constant), Occupational environment

Coefficients $^{\mathrm{a}}$

\begin{tabular}{|c|c|c|c|c|c|}
\hline \multirow[t]{3}{*}{ Model } & \multicolumn{2}{|c|}{ Unstandardized } & \multirow{3}{*}{$\begin{array}{l}\text { Standardized } \\
\text { Coefficients } \\
\text { Beta }\end{array}$} & \multirow[t]{2}{*}{$\mathrm{t}$} & \multirow[t]{2}{*}{ Sig. } \\
\hline & Coeffic & & & & \\
\hline & & Std. Error & & & \\
\hline (Constant) & 1.472 & 0.171 & & 8.624 & 0.000 \\
\hline $\begin{array}{c}1 \text { Occupational } \\
\text { environment }\end{array}$ & 0.585 & 0.053 & 0.529 & 11.063 & 0.000 \\
\hline \multicolumn{6}{|c|}{ a. Dependent Variable: Employee Performance } \\
\hline
\end{tabular}

From the table 4.13 above the value of $\mathrm{R}$ square was 0.280 this shows that occupational environment explains $28.0 \%$ of variance in employee performance in sugar industries in Western Kenya. From the ANOVA table significance of the model has a value F $(1,316)$ $=122.391, \mathrm{P}<0.01$ this shows that it's significant at $99 \%$ confidence level hence the model is feasible. This implies that occupational environment is a useful predictor of employee performance in sugar industries in Western Kenya. The unstandardized regression coefficient value of occupational environment was 0.585 and significance level of $\mathrm{p}<.001$. This indicated that a unit change in occupational environment would result to significant change in employee performance by 0.585 .

\subsection{Discussion}

The objective of the study was to find out the effects of occupational health and safety on employee performance in Sugar manufacturing industries in Western Kenya. The independent variable was occupational environment. A total of 380 questionnaires were distributed and 317 valid questionnaires were returned. This implies that the response rate was $83.7 \%$ of the sample size. The lookup units were observed to be reliability as the Cronbach alpha ranged from 0.704 to 0.880 . Further, the instrument was observed to be valid as printed via sampling adequacy.

Pearson Correlation effects a robust relationship between occupational environment and employee overall performance in sugar industries as proven by means of a coefficient of correlation ( $\mathrm{r}$ ) as $0.529 * *$. Linear regression analysis indicated that occupational surroundings notably bills up to $28.0 \%$ of variance in employee overall performance in sugar industries in Western Kenya $(\mathrm{R}=0.280)$. Multiple regression evaluation printed that when other variables are managed in the model, a unit trade in occupational environment would effect to a widespread exchange in worker performance by using 0.282 in the equal direction. The unique goals of Occupational Environment and Employee Performance have been achieved through conducting Pearson correlation evaluation and linear regression analysis. Pearson correlation produced $\mathrm{R}$ while simple linear regression produced $\mathrm{B}$-coefficients and $\mathrm{R}$ square (coefficient of determination).

\section{Conclusions}

Based on the empirical evidence, a range of logical conclusions can be made as follows and in terms of find out about goals so as to accurately reply research questions as follows. 
From the linear and a couple of regression results on Occupational Environment and Employee Performance concluded that occupational surrounding has significant impact on worker overall performance in sugar industries in Western Kenya. An enhancement in occupational environment in relation to occupational and health protection would have consequences to substantially improve worker performance in sugar industries in Western Kenya. It used to be now not the adequacy of fire fighting equipment at work environment are average as well as people are rather provided with emergency strategies which are in many instances tested. However, there was once low provision of emergency approaches which are often tested at the work environment. Therefore, occupational surroundings affects employee overall performance in sugar industries in Western Kenya.

\section{References}

Abuga, G. (2012). A Case Study on the Effects of Occupational Health and Safety Programs onOrganizational Effectiveness, Kenyatta University: Unpublished.

Armstrong. (2015). Strategic Human Resource Management Practice, 1th Edition, London: KoganPage.

Badelake. (2012). The Effects of Occupational Health and Safety Practices on Employee Performance in Larfage (WAPCO) PLC -. Ewekoro, Ogun State,: Unpublished University of Ibadan Nigeria.

Bill, \& Samuel. (2012). Key Issues on Occupational Health and Safety Practices in Ghana. International Journal of Business and Social Science, 3(19).

Boles, Pelletier, \& Lynch. (2012). Employee Attitude towards health risks and work productivity in South Africa. Journal of Occupational and Environmental Medicine, 46(7), 737-745. https://doi.org/10.1097/01.jom.0000131830.45744.97

Chandrasekar. (2011). Workplace Environment and its Impact on Organizational Performance in Public Sector Organizations,. International Journal Of Enterprise Computing and Business Systems, 1(1), 21-23.

Hiagro. (2016). Environmental \& Social Impact Assessment Study Report Proposed Sugar Complex for Tembo Sugar Mills Ltd. Nairobi: Hiagro (EA) Services Limited.

Indakwa. (2013). A Cross-Sectional Study on the Perceived Influence of Occupational Health and Safety programs on Job Performance, . University of Nairobi, Kenya: Unpublished,.

Ikpa. (2011). An Assessment of Occupational Health and Safety Practices on Job Performance at the Tetteh Quashire Memorial Hospital, Manopang Akuapan,. Ghana.: Kwame Nkrumah University Publishers.

KESREDIGEST. (2015). A newsletter of the Kenya sugar Research foundation. Volume 3 issue July- August-September.

Lim. (2012). OHS management system: Three benefits for construction enterprise.

Makori. (2012). Influence of occupational health and safety programmes on performance of 
manufacturing firms in former Western province, Kenya. Masinde Muliro University of science and technology. African Journal of History and culture, 4(4), 46-58. https://doi.org/10.5897/AJHC11.036

Mutemi. (2014). A survey of the Occupational Health and Safety Programmes adopted by chemical manufacturing firms in Nairobi. University of Nairobi.: Unpublished MBA Research Project.

Mutuli, Lubwama, \& Marenya. (2016). Hot working environments: a critical look at a typical sugar manufacturing concern in kenya. Global Ergonomics, 1(11), 606-619. https://doi.org/10.1016/B978-008043334-9/50065-2

Niemela, \& Hannula. (2012). The Effect of Indoor Air Temperature on Labour Productivity in Call Centers: A Case Study. Energy and Building Journal, 34(3), 759-764. https://doi.org/10.1016/S0378-7788(02)00094-4

Pollitt. (2011). Corus forges new approach to safety and health. . Human resource management international digest, 19(7-9). https://doi.org/10.1108/09670731111101516

Prabakar. (2013). A case study with special reference to Don Bosco College Ndirangu, \& Namusonge. (2014). Factors influencing implementation of occupational health and safety: A case study of Kenya vehicle manufacturers in Thika. . International Journal of Social Sciences and Entrepreneurshipof Arts and Science, Sogathur, Dharmapuri, Asia Pacific Journal of Research: Welfare measure and workers satisfaction, , Volume:3, Issue:10.

Samuelson, \& Nordhaus. (2014). Economics (13th ed.). New York, N: McGraw-Hill.

Simiyu Bisela Sylvia. (2013). Efects of Employee Motivation on Performnace in Public Universities in Western Kenya. Undergraduate Graduation Report, Masinde Muliro University of Science and Technology (MMUST).

Srinivas. (2013). A study on employee welfare facilities adopted at Bosch Limited, Bangalore . Research Journal of Management Science , 2(12), 7-11.

WHO. (2013). Healthy Workplace Framework and Model: Background and Supporting Literature and Practices,. Geneva, Switzerlan: WHO Press.

\section{Copyright Disclaimer}

Copyright for this article is retained by the author(s), with first publication rights granted to the journal.

This is an open-access article distributed under the terms and conditions of the Creative Commons Attribution license (http://creativecommons.org/licenses/by/4.0/). 